Jan M. KOZŁOWSKI*

\title{
CIEŚLA I KRZYŻ
}

\begin{abstract}
Pogański filozof Celsus w 178 r. po Chr. pisał w swoim Prawdziwym Stowie:

„Gdyby jednak przypadkiem został strącony ze skały, wtrącony w przepaść albo uduszony sznurem [...] wówczas w niebie byłaby skała życia, kamień zmartwychwstania albo sznur nieśmiertelności"1.
\end{abstract}

Ile w tym racji? Czyżby śmierć na krzyżu miała być jednym z wielu rodzajów śmierci, jaka mogła spotkać cieślę z Nazaretu?

Krzyż, narzędzie kaźni, na którym Jezus poniósł śmierć, był dla starożytnych nieporównywalnie silniej przemawiającym symbolem niż jest obecnie dla nas. Dlatego też, by właściwie czytać ten znak męki i zmartwychwstania Jezusa, musimy spojrzeć wstecz na kontekst kulturowy, w jakim śmierć Jezusa miała miejsce.

Kaźń krzyżowa, przeznaczona dla buntowników i niewolników, wyrażała właściwie wszystko to, co dla starożytnych było niegodne, podłe, poniżające. Cyceron (I w. przed Chr.) nazywa ukrzyżowanie wprost: „ostateczną i najsurowszą karą dla niewolników (servitutis extremum summumque supplicium)"2. Gdzie indziej zaś zaleca, aby: „,samo słowo «krzyż» (nomen ipsum crucis) było jak najdalej nie tylko od ciała rzymskich obywateli, ale także od ich myśli, oczu i uszu"3. Również Nowy Testament mówi o krzyżu, jako o śmierci haniebnej: „on to zamiast radości, którą Mu obiecywano, przecierpiał krzyż, nie bacząc na jego hańbę” (Hbr 12, 2), a także: „uniżył samego siebie, stawszy się posłusznym aż do śmierci - i to śmierci krzyżowej” (Flp 2,8).

* Dr Jan M. Kozłowski - adiunkt w Zakładzie Literatur i Języków Klasycznych w Instytucie Filologii Klasycznej na Wydziale Polonistyki Uniwersytetu Warszawskiego; e-mail: jan.kozlowski@, uw.edu.pl.

${ }^{1}$ Origenes, Contra Celsum VI 34, ed. M. Marcovich, Origenes, Contra Celsum libri VIII, Supplements to Vigiliae Christianae 54. Texts and Studies of Early Christian Life and Language, Leiden - Boston - Köln, 410-411, thum. S. Kalinkowski, Orygenes, Przeciw Celsusowi, Warszawa 1986, 309.

${ }^{2}$ Cicero, In Verrem II 5, 169, ed. W. Peterson, M. Tulii Ciceronis orationes, III, Oxford Classical Texts, Oxford 1963, 456; wszystkie teksty starożytne, jeśli nie jest zaznaczone inaczej, podaję w moim thumaczeniu; cytaty biblijne podaję w thumaczeniu Biblii Tysiąclecia (wyd. 5).

${ }^{3}$ Tenże, Pro Rabirio Perduellionis Reo 16, ed. A.C. Clark, M. Tulii Ciceronis orationes, IV, Oxford Classical Texts, Oxford 1993, 187. 
Chrześcijanie od samego początku dostrzegali w księgach Starego Testamentu prefiguracje ukrzyżowanego Mesjasza. Zupełnie fantastyczną listę takich proroctw podaje chrześcijański filozof Justyn (2. poł. II w.) w swoim Dia$\operatorname{logu} z \dot{Z} y d e m$ Tryfonem ${ }^{4}$. Justyn twierdzi między innymi, że Ukrzyżowanego zapowiadają: zasadzone w raju „drzewo życia”; laska, którą Mojżesz otworzył Morze Czerwone (por. Wj 14, 16. 21) i którą na pustyni wyprowadził wodę ze skały (por. Wj 17, 5-6); drewno w miejscowości Mara, które na polecenie Boga Mojżesz wrzucił do wody, a ta stała się słodka (por. Wj 15, 25). Justyn dostrzega zapowiedź krzyża także w drabinie Jakuba (por. Rdz 28, 12-15) oraz lasce Aarona, która „wypuściła pączki, i zakwitła” (Wj 17, 23). To tylko niektóre z przytaczanych przez Justyna miejsc ze Starego Testamentu, w których chrześcijanie dostrzegali prefigurację i zapowiedź Chrystusowego krzyża, ale już po tym wyborze widać jak silnym i wielowymiarowym symbolem był dla chrześcijan krzyż oraz na jakie jego wymiary medytujący mękę Pańską chrześcijanin może się otwierać.

Krzyż był dla pierwszych chrześcijan również symbolem kosmicznym. Zaważył tutaj autorytet Platona, który w swoim dialogu Timajos ${ }^{5}$, w niezwykle zawiłym i w znacznej części niezrozumiałym wywodzie o stworzeniu przez Boga-demiurga „duszy wszechświata”, twierdzi, że ekliptyka i niebieski równik przecinają się ze sobą pod kątem prostym tworząc kształt greckiej litery khi $(\mathrm{X})$, a wokół tego przecięcia obraca się cały nieboskłon. Miejsce to chrześcijanom (tym, którzy czytali Platona) automatycznie przywodziło na myśl nie tylko krzyż Chrystusa, ale także prawdę o przedwiecznym Logosie $\mathrm{z}$ Prologu Janowego. Expressis verbis do tego miejsca nawiązuje wspomniany wyżej Justyn, który w swojej Apologii pisze o Platonie ${ }^{6}$ : „Mimo że nie pojął,

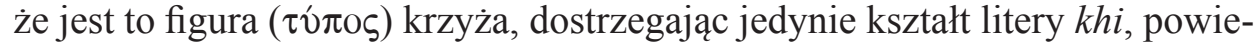
dział, że «druga po Bogu moc została rozpostarta po wszystkim»" na interpretacja krzyża pojawia się następnie u innych Ojców Kościoła, jak Ireneusz z Lyonu ${ }^{8}$ czy Grzegorz z Nyssy9.

Przekonanie, że znak krzyża wpisany jest w naturę i otaczającą człowieka rzeczywistość, dochodzi do głosu w łacińskim dialogu Oktawiusz Minucjusza Feliksa z początku III w., w którym tytułowy chrześcijanin Oktawiusz zwraca się do swojego przyjaciela poganina Cecyliusza słowami:

${ }^{4}$ Por. Justinus, Dialogus cum Tryphone 86.

${ }^{5}$ Por. Plato, Timaios 36B-C.

${ }^{6}$ Por. Justinus, Apologia I 60, 5, ed. C. Munier, SCh 507, Paris 2006, 286.

${ }^{7}$ Plato, Timaios 36B-C..

${ }^{8}$ Por. W. Myszor, Symbolika krzyża wedlug św. Ireneusza, SSHT 30 (1997) 97-102; P. Szczur, Krzyż jako fundament kosmosu w nauczaniu Ireneusza z Lyonu i Jana Chryzostoma, w: Krzyż twój wielbimy, red. A. Paciorek, Tarnów 2011 = „Scripturae Lumen” 3 (2011) 411-428.

${ }^{9}$ Por. M. Canévet, La croix cosmique chez Grégoire de Nysse, w: La Croix. Représentations théologiques et symboliques. Journée d'étude du jeudi 19 septembre 2002, organisée à Strasbourg par le Centre d'Analyse et de Documentation Patristiques (AcR), ed. J.M. Prieur, Genève 2004, 81-88. 
„Czymże innym, jak nie ozdobnymi i pozłoconymi krzyżami są wasze znaki wojskowe i sztandary? Wasze trofea zwycięstwa nie tylko przypominają kształt prostego krzyża, ale wręcz rozpiętego na nim człowieka. Znak krzyża tworzy przecież sama z siebie konstrukcja statku, gdy wydęte żagle porywają go do przodu, lub też gdy przy podniesionych wiosłach utrzymuje się na powierzchni wody. Tak samo i jarzmo w zaprzęgu przypomina krzyż oraz człowiek, gdy wyciągnąwszy ręce, samą myślą czci Boga"10.

Widać zatem, że krzyż dla starożytnych chrześcijan miał niezwykle bogatą symboliczną wymowę. W pierwszej kolejności to znak poniżenia, które dla ludzi naszej kultury, nieporównywalnie mniej zhierarchizowanej niż starożytna, jest trudne do pojęcia. Jednocześnie symbolika ta nie wyklucza kosmicznej symboliki krzyża ani jego chwalebnych prefiguracji w Starym Testamencie. Kontemplujący krzyż chrześcijanin może uwzględniać jednocześnie wszystkie te wymiary.

Ci którzy oglądali Ostatnie Kuszenie Chrystusa Martina Scorsese, film oparty na noszącej ten sam tytuł powieści Nikosa Kazantzakisa, z pewnością pamiętają scenę z początku filmu, gdzie Jezus niemal maniakalnie struga krzyże. Obraz ten, ilekroć oglądałem ten film, wywoływał we mnie pewien niepokój, ale dopiero niedawno udało mi się zwerbalizować pytanie, jakie we mnie rodził. Brzmi ono: czy istnieje związek między śmiercią krzyżową Jezusa a faktem, że Jezus był, jak mówi Ewangelia Marka, cieślą: „Czy nie jest to

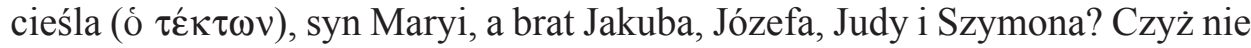
żyją tu u nas także Jego siostry?” (Mk 6, 3). A jeśli tak, to na czym ten związek może polegać? Niżej spróbuję udzielić jednej z zapewne wielu możliwych odpowiedzi.

„A Słowo stało się ciałem i zamieszkało wśród nas” (J 1, 14). Słowa te są streszczeniem Dobrej Nowiny i właściwym początkiem chrześcijaństwa. Wszystko, co specyficznie chrześcijańskie stanowi konsekwencje tego wydarzenia. Odwieczny Bóg stał się człowiekiem, zapowiedzianym przez proroka Izajasza Emmanuelem - „Bogiem z nami” (Iz 7, 14). Kiedy jest mowa o Jezusie Chrystusie, właśnie ta optyka jest dla większości chrześcijan pierwszorzędna.

${ }^{10}$ Minucius Felix, Octavius 29, ed. B. Kytzler: Minucius Felix, Octavius, München 1965, 166168, tłum. M. Szarmach w: Minucjusz Feliks, Apologie, PSP 44, Warszawa 1988, 64. Również w wyżej już cytowanej Apologii Justyna czytamy: „Pomyślcie tylko, czy wszystko, co istnieje we wszechświecie, może istnieć samo w sobie, czy też tworzyć pewną całość bez tego znaku? Okręt nie może płynąć po morzu, jeśli nie został postawiony na nim znak zwany żaglem. Ziemi również się nie orze bez tego znaku. Rolnicy i rzemieślnicy nie wykonują swojej pracy bez narzędzi w kształcie tego właśnie znaku. Ludzka postać niczym innym nie różni się od zwierząt nierozumnych, jak tym, że człowiek przyjmuje postawę prostą i może wyciągnąć ręce, a na jego twarzy rozciąga się to, co nazywane jest nosem, który zwierzętom służy do oddychania, zaś u człowieka nic innego nie wskazuje, jak znak krzyża” (Justinus, Apologia I 55, 2-4, SCh 507, 274-276, tłum. L. Misiarczyk w: Pierwsi apologeci greccy, BOK 24, Kraków 2004, 247. 
Tę perspektywę można jednak odwrócić. Mateusz już na początku swojej Ewangelii wyprowadza rodowód Jezusa od Abrahama (Mt 1, 1-17). Przesłanie jest jasne. Jezus Chrystus jest Żydem pochodzącym, przez króla Dawida, w prostej linii od Abrahama. Trzeci ewangelista idzie dalej. Łukasz wyprowadza rodowód Jezusa od „Adama, syna Bożego” (Łk 3, 38). W ten sposób, pisząc swą Ewangelię w czasach, gdy zaczęły się już pojawiać wśród chrześcijan poglądy doketystyczne, kwestionujące realne człowieczeństwo Jezusa, Łukasz chce czytelnikom swojej Ewangelii powiedzieć, że Jezus jest, mówiąc językiem biologii, homo sapiens, pochodzącym od tej samej co my mitochondrialnej Ewy. Po niemal dwu tysiącach lat ewangeliście wtóruje Sobór Watykański II, który przypomina: „ludzkimi rękoma pracował, ludzkim myślał umysłem, ludzką działał wolą, ludzkim sercem kochał"11. A zatem historia Jezusa to historia człowieka takiego jak my. Możemy dodać, że tak jak każdy człowiek Jezus chorował, mógł być zakochany, czasem powiedział dowcip, z którego nie wszyscy się śmiali... Wprawdzie Sobór Watykański II przypomniał, że Jezus był „we wszystkim do nas podobny oprócz grzechu” (Hbr 4, $15)^{12}, \mathrm{z}$ pewnością jednak bezgrzeszność Jezusa nie może polegać na czymkolwiek, co w ludzkich oczach mogłoby Go w jakikolwiek sposób „odczłowieczyć". Dość powiedzieć, że z kart Ewangelii wiemy, że nie polegała ona ani na szczególnie skrupulatnym przestrzeganiu przez Niego przykazań (np. Mt 12, 1-5), ani na niezłomności charakteru (np. Mt 26, 37-39), ani na szczególnym umiłowaniu umiarkowania w jedzeniu i piciu (np. Mt 11, 19; Łk 7, 34). Jezus, parafrazując św. Augustyna ${ }^{13}$, po prostu „kochał i robił co chciał”. Wcielony, przedwieczny Syn Boży nie jest zatem żadnym wszech-człowiekiem przyobleczonym w uniwersalną ludzką naturę, ale „normalnym” człowiekiem o imieniu Jeszua (Jezus to zhellenizowana forma tego imienia), który mieszkał w Nazarecie na początku pierwszego tysiąclecia naszej ery, zupełnie analogicznie do tego, jak ja nazywam się Jan i mieszkam w Warszawie na początku trzeciego tysiąclecia. I właśnie ten jeden z setek tysięcy Żydów zamieszkujących ówczesną Palestynę został rozpoznany (i tu zaczyna się chrześcijaństwo) jako... przedwieczny Bóg.

Wszystko, co specyficznie chrześcijańskie ma więc swoją przyczynę we wcieleniu. Konsekwencje tego wydarzenia są również tam, gdzie na co dzień ich istnienia sobie nie uzmysławiamy. Blask zwycięstwa Zmartwychwstałego tak nas oślepia, że nie często zatrzymujemy się nad tym, że zmartwychwstały Jezus pojawił się apostołom właśnie w Jerozolimie (czyli tam, gdzie został stracony) a następnie wyprowadził ich z powrotem do Galilei - ich wspólnej ojczyzny (Mt 28, 16). Rzadko zastanawia nas fakt, że Jezus po zmartwychwstaniu je dokładnie to samo, co było powszednim pokarmem Galilejczyka:

${ }^{11}$ Vaticanum II, Gaudium et spes 22, ed. i thum. Sobór Watykański II. Konstytucje, Dekrety, Deklaracje, Tekst łacińsko-polski, Paris 1967, 556-557.

12 Tamże.

${ }^{13}$ Por. Augustinus, In Epistulam Ioannis ad Parthos tractatus 7, 8. 
ryby, chleb, wino ( $Ł k$ 24, 41-43; Dz 10,41). Jezus kontynuuje historię wcielenia również po swoim zmartwychwstaniu!

Konkret wcielenia przekłada się także na codzienną rzeczywistość wiary chrześcijan. Obrzęd chrztu to przecież naśladowanie zanurzenia w wodach Jordanu, tej samej rzeki, o której informacje można teraz znaleźć w Wikipedii. Podobnie jest z Eucharystią, nazywaną „,chlebem anielskim”, a przecież wywodzącą się, w swej pierwotnej tkance z obchodzonego przez rolniczą ludność Izraela święta dziękczynnego za pierwociny z pól. Jak bardzo Eucharystia jest związana z konkretem wcielenia, może nam uzmysłowić to, że o ile dla ludzi żyjących w basenie Morza Śródziemnego wino i chleb to pokarm ,powszedni” par excellence, to już dla Eskimosów, nie znających ani zboża, ani winorośli, zrozumienie symboliki eucharystycznego pokarmu wymaga nieporównywalnie większego wysiłku. Zastąpienie w Azji chleba przez opłatek ryżowy z jednej strony z pewnością zobiektywizowałoby płynące z Eucharystii przesłanie, z drugiej jednak zadałoby kłam istocie wiary chrześcijan, którzy czczą cieślę z Nazaretu umęczonego i zmartwychwstałego właśnie w Judei pod panowaniem rzymskiego namiestnika nazywającego się Pontius Pilatus, a nie gdzie i kiedy indziej. Nie inaczej ma się też rzecz z symboliką krzyża, która cała bez reszty jest zapośredniczona przez wydarzenie wcielenia ${ }^{14}$. I właśnie w tej perspektywie chciałbym spojrzeć na związek między faktem, że Jezus był cieślą, a tym, że poniósł śmierć na drzewie krzyża.

W swoim Prawdziwym Stowie Celsus, który traktował całe chrześcijaństwo ze wszystkimi jego odłamami jako jeden front, tak pisze o nauce gnostyckiej sekty ofitów:

„Jest tam drzewo życia, jest tam zmartwychwstanie ciała za sprawą drzewa; dlatego sądzę, że ich nauczyciel został przybity do krzyża, a z zawodu był cieślą"15.

Choć nie ma tu bezpośredniego związku między ukrzyżowaniem a faktem, że Jezus był cieślą, w słowach tych można jednak się takiego pośredniego związku dopatrzeć: nieco wcześniej (we fragmencie przytoczonym na początku artykułu) Celsus łączy drzewo krzyża z drzewem życia. Jednak to nie Prawdziwe Stowo, ale apokryficzna Ewangelia Filipa odkryta w 1945 r. w Nag Hammadi dostarcza nam bodaj najstarszego i najbardziej wyraźnego skojarzenia tych dwóch rzeczywistości. Czytamy w niej, co następuje:

„Józef, cieśla, zasadził ogród, gdyż potrzebował drzewa dla swego rzemiosła. On to jest tym, który wyciosał krzyż z drzew, które zasadził. Jego poto-

${ }^{14}$ Również kosmiczna symbolika krzyża jest skutkiem wcielenia, ponieważ nie-wcielony Bóg jest nieskończenie ponad wszelkim wyobrażeniem i poza jakimikolwiek współrzędnymi. Silniej może jednak odczuwamy rzeczywistość wcielenia w krzyżu jako symbolu poniżenia i upokorzenia, która jest znakiem czasu rzymskiej okupacji Judei. Gdyby śmierć Jezusa miała miejsce sto lat wcześniej czcilibyśmy (i tu Celsus ma rację) raczej kamienie, którymi Jezus byłby ukamienowany.

${ }^{15}$ Origenes, Contra Celsum VI 34, ed. Marcovich, s. 410, thum. Kalinowski, s. 309. 
mek zawisł na tym, co on zasadził. Jego potomkiem był Jezus, zaś sadzonką krzyż" ${ }^{\prime 16}$.

Nie wnikając w to, jakie jest możliwe stricte gnostyckie znaczenie tego fragmentu ${ }^{17}$, znajdujemy tutaj bezpośredni związek między ukrzyżowaniem Jezusa a faktem, że był cieślą. Krzyż Jezusa jest nazwany „sadzonką” Józefa-cieśli.

W świetle tego, co zostało napisane wyżej, dostrzeżenie, w kontekście śmierci krzyżowej, faktu, że Jezus był cieślą pozwala dostrzec kolejne piętro tajemnicy wcielenia. Drewno, z którego wykonane było to straszne narzędzie, było pierwszym żywiołem Jego codziennego ciesielskiego doświadczenia ${ }^{18}$. Jego ,ś́więte i czcigodne ręce” były na krzyżu przybite do materiału, który obracały przez całe Jego wypełnione pracą życie. Poranione plecy przywarły do drewna, które nieraz w ciesielskim warsztacie zwilżyła Jego krew. W świetle tej korespondencji lepiej możemy dostrzec związek między Golgotą i Nazaretem. Oto w ukrytym życiu w Nazarecie namacalnie dostrzegamy początek kenozy Syna Bożego, zapowiedź jego „śmierci krzyżowej” (Flp 2, 6-8). Jednocześnie, odwracając tę perspektywę, w wywyższeniu Syna Bożego na krzyżu można dostrzec realizację planu zbawienia świata, którego Bóg dokonał właśnie przez wcielenie się w osobę cieśli z Nazaretu, wcielenie urzeczywistnione przez narodzenie się w rodzie „Adama, syna Bożego”, którego cała historia zmierzała ku Niemu. Zawód cieśli sięga w głąb rodziny Jezusa, skoro

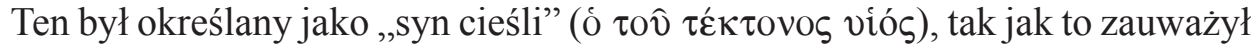
autor Ewangelii Filipa twierdząc, że drewno krzyża pochodziło z drzew, które Józef zasadził w swoim ogrodzie. A zatem przybity na Golgocie do krzyża Jezus, obecny jest tam z całą historią swojego Adamowego rodu. Drzewo życia wyrasta z żyznej wydającej stukrotny plon gleby - prawdziwego Boga, ale i nie mniej prawdziwego człowieka, którego ,podstawowy wymiar bytowania stanowi praca" 19 .

${ }^{16}$ Evangelium Philippi 91, NHC II 73, 9-15, thum. A. Dembska-W. Myszor: Ewangelia Filipa, w: Teksty z Nag Hammadi, PSP 20, Warszawa 1979, 262.

${ }^{17}$ Por. W. Myszor, Symbolika krzyża wedtug św. Ireneusza, s. 98, nota 18: „Nie jest wykluczone, że gnostycy wykorzystali motyw, który odwoływał się do rozumienia drzewa jako materii, to jest do wieloznaczności greckiej hyle raz jako «drzewo» a raz jako «materia» w znaczeniu filozoficznym. Wówczas wydaje się możliwe, że według gnostyków potomek Józefa został zawieszony na drzewie jako materii świata”.

${ }^{18}$ Każda wioska i miasteczko w Izraelu miały swoich cieśli, którzy robili sprzęt dla miejscowych rolników: pługi, radła, sochy etc, słowem wszystko, co było z drewna. Nie da się wykluczyć, że Józef i Jezus mogli przynajmniej raz w życiu (żyli przecież pod okupacją rzymską) wykonać na zamówienie krzyżową belkę. W każdym razie było to coś, co wchodziło w zakres wykonywanego przez nich zawodu.

${ }_{19}$ Jan Paweł II, Laborem exercens 2, 4, w: Encykliki Ojca Świętego Jana Pawła II, I, Kraków 1996, 109. 
THE CARPENTER AND THE CROSS

(Summary)

A close relationship exists between Jesus' death on the cross and the fact that Jesus was a carpenter. Wood, from which the tool of Jesus' execution was fashioned, was also the dominant element of the Son of God's everyday experience. In the light of this correspondence one can see God's plan, according to which there is a strong link not only between Nazareth and Golgotha, but also between the „cross" carried by a Christian and the content of his everyday life.

Słowa kluczowe: krzyż, cieśla, Jezus, Józef, praca, wcielenie, Nazaret.

Key words: cross, carpenter, Jesus, Joseph, job, incarnation, Nazareth. 
